\title{
EVALUASI KINERJA PETUGAS VAKSINASI RABIES DI KOTA AMBON
}

\author{
EVALUATION OF RABIES VACCINATOR'S PERFORMANCE IN AMBON
}

\author{
Astri Dwyanti Tagueha ${ }^{1}$, Heru Susetya ${ }^{2}$, Setyawan Budiharta ${ }^{2}$
}

\author{
${ }^{1}$ Fakultas Peternakan, Universitas Pattimura \\ ${ }^{2}$ Bagian Kesehatan Masyarakat Veteriner, Fakultas Kedokteran Hewan, Universitas Gadjah Mada, \\ Yogyakarta \\ E-mail: acit_tags@yahoo.com
}

\begin{abstract}
Study on the evaluation of rabies vaccinator performance and its associated factors on has been conducted. A number of 21 vaccinators were interviewed using a questionnaire which have been tested twice to obtain good validity and reliability. The results showed that vaccinators have high motivation $(52.38 \%)$ and good coordination (57.14\%). Vaccinator's knowledge about rabies was mediocre and most of them did not know about cold chain management (57.14\%). Facilities to support vaccination are available in limitied quantities (52.38\%). Vaccinators with good performance are $61.90 \%$. The results of bivariate test showed that factors associated with vaccinator performance were motivation $(\mathrm{OR}=23.33)$, facilites $(\mathrm{OR}=15.75)$, and coordination $(\mathrm{OR}=9.17)$. The model of vaccinator performance value based on linear regression was : Square root of PERFORMANCE $=2.28982+0.06258$ KNOWLEDGE + 0,05482 FACILITES. An improvement of vaccinator's performance trained vaccinator and the availability of facilities could motivate the vaccinator work.
\end{abstract}

Key words : rabies, vaccinator performance, association, linear regression

\section{ABSTRAK}

Kajian tentang evaluasi kinerja petugas vaksinasi rabies di Kota Ambon dan faktor-faktor yang memengaruhinya telah dilaksanakan. Sebanyak 21 orang petugas vaksinasi diwawancarai dengan kuesioner yang sebelumnya telah diuji dua kali untuk mendapatkan validitas dan reliabilitas yang diinginkan. Hasil penelitian memperlihatkan petugas memiliki motivasi yang tinggi $(52,38 \%)$ dan koordinasi baik $(66,67 \%)$. Pengetahuan petugas tentang rabies sangat kurang dan sebagian besar belum sepenuhnya paham tentang penanganan rantai dingin $(57,14 \%)$. Sarana penunjang vaksinasi tersedia dalam jumlah terbatas $(52,38 \%)$. Petugas yang memiliki kinerja baik berjumlah $61,90 \%$. Kinerja petugas berasosiasi secara bivariat dengan motivasi $(O R=23,33)$, sarana $(O R=15,75)$, dan koordinasi $(O R=9,17)$. Model nilai kinerja petugas vaksinasi rabies di Kota Ambon berdasarkan analisis regresi linear yaitu : KINERJA= 2,28982 + 0,06258 PNGTHUAN $+0,05482$ SARANA. Peningkatan pengetahuan dan ketersediaan sarana penunjang diharapkan meningkatkan kinerja petugas vaksinasi rabies di Kota Ambon.

Kata kunci : rabies, kinerja petugas vaksinasi, asosiasi, regresi linear 


\section{PENDAHULUAN}

Laporan kasus rabies baik pada manusia maupun hewan masih dijumpai di kawasan Asia Tenggara, khususnya Indonesia. Berbagai upaya pengendalian telah diterapkan, namun belum banyak daerah yang berhasil dibebaskan. Pada tahun 2010, tercatat hanya 11 provinsi yang dinyatakan bebas rabies. Kota Ambon merupakan daerah endemis rabies sejak tahun 2003. Pengendalian rabies di Kota Ambon dilakukan melalui vaksinasi massal anjing setiap tahunnya. Kegiatan ini mampu mengurangi korban jiwa selama 6 tahun terakhir yaitu dua hingga tiga kasus kematian per tahun, walaupun kasus gigitan dan permintaan vaksin anti rabies (VAR) tetap fluktuatif(Anonimous, 2010b). Eliminasi tidak dapat diterapkan karena adanya tuntunan ganti rugi oleh pemilik anjing.

Vaksinasi massal dilakukan dengan metode kunjungan rumah ke rumah oleh 21 orang petugas vaksinasi yang secara resmi ditunjuk oleh Dinas Pertanian dan Kehutanan Kota Ambon. Petugas vaksinasi bertanggung jawab terhadap upaya pengendalian rabies di daerah endemik. Hasil kerja mereka turut memengaruhi terciptanya rasa aman di tengah masyarakat yaitu dengan terlindungnya populasi anjing sebagai indikator utama keberhasilan vaksinasi.

Evaluasi kinerja petugas vaksinasi diperlukan untuk mengetahui efektivitas vaksinasi. Evaluasinya dapat berupa penilaian kualitas maupun kuantitas. Jika didasarkan pada aspek kuantitas, petugas vaksinasi rabies di Kota Ambon telah menjalankan tugasnya dengan baik. Penilaian kualitas berkaitan dengan cara penanganan vaksin di lapangan dan turut menentukan titer antibodi pascavaksinasi. Kinerja seseorang dipengaruhi oleh lingkungan eksternal, faktor internal pegawai, dan lingkungan internal organisasi (Wirawan, 2009). Peneliti sebelumnya menemukan hubungan antara kinerja petugas vaksinasi dengan sejumlah faktor individu dan organisasi (Ariebowo, 2005; Mukhlis, 2006; Rachmawati, 2007), namun kesemuanya terfokus pada pelayanan untuk manusia. Penelitian ini bertujuan untuk mengetahui kinerja petugas vaksinasi rabies di Kota Ambon dan faktor-faktor yang memengaruhinya.

\section{MATERI DAN METODE}

Semua petugas vaksinasi (21 orang) diwawancarai dan berpedoman pada kuesioner dengan pertanyaan terstruktur. Kuesioner yang dipakai sebelumnya telah diuji sebanyak dua kali untuk mendapatkan validitas dan reliabilitas yang diinginkan dengan pendekatan korelasi Pearson Product Moment dan Alfa Cronbach (Riyanto, 2009; Riwidikdo, 2009).

Kinerja petugas dianggap sebagai variabel dependen ( $Y$ ) sedangkan faktor motivasi, pengetahuan, sarana, dan køordinasi ditetapkan sebagai variabel independen (X). Kinerja dikategorikan baik dan kurang berdasarkan rerata total jawaban semua responden. Kriteria yang sama dipakai untuk mengategorikan variabel motivasi, pengetahuan, sarana, dan koordinasi. Data dianalisis secara deskriptif, chi square untuk mengetahui asosiasi, dan regresi linear untuk mengetahui model kinerja petugas vaksinasi rabies. 


\section{HASIL DAN PEMBAHASAN}

Petugas vaksinasi rabies di kota Ambon berumur $46,7 \pm 4,13$ tahun dan didominasi oleh lulusan SMA/SMK $(52,4 \%)$. Seluruh petugas vaksinasi adalah pegawai negeri sipil dalam lingkup Dinas Pertanian dan Kehutanan kota Ambon. Secara keseluruhan, petugas vaksinasi memiliki motivasi tinggi $(52,38 \%)$ dan koordinasi baik $(66,67 \%)$. Pengetahuan umum tentang rabies dan vaksinasi masih kurang $(57,14 \%)$. Sebagian besar mengakui sarana penunjang vaksinasi tersedia dalam jumlah terbatas $(52,38 \%)$. Petugas yang memiliki kinerja baik berjumlah $61,90 \%$. Tabel 1 memperlihatkan faktor motivasi, sarana, dan koordinasi berasosiasi dengan kinerja petugas vaksinasi.

Tabel 1. Chisquare $\left(\chi^{2}\right)$ dan OR antara kinerja petugas vaksinasi rabies dan faktor independen

\begin{tabular}{|c|c|c|c|c|c|c|}
\hline \multirow{2}{*}{ No } & \multirow{2}{*}{ Variabel } & \multirow{2}{*}{ Kategori } & \multicolumn{2}{|c|}{ Kinerja } & \multirow{2}{*}{ Chi square $\left(\chi^{2}\right)$} & \multirow{2}{*}{$\begin{array}{c}\text { OR } \\
(95 \% \\
\text { CI) }\end{array}$} \\
\hline & & & Baik & Kurang & & \\
\hline 1 & Motivasi & $\begin{array}{l}\text { Tinggi } \\
\text { Rendah }\end{array}$ & $\begin{array}{c}10 \\
3\end{array}$ & $\begin{array}{l}1 \\
7\end{array}$ & $8,24^{* *}$ & $\begin{array}{c}23,33 \\
(1,99-273,29)\end{array}$ \\
\hline 2 & Pengetahuan & $\begin{array}{l}\text { Tinggi } \\
\text { Rendah }\end{array}$ & $\begin{array}{l}9 \\
4\end{array}$ & $\begin{array}{l}0 \\
8\end{array}$ & $9,69^{* *}$ & M \\
\hline 3 & Sarana & $\begin{array}{l}\text { Memadai } \\
\text { Terbatas }\end{array}$ & $\begin{array}{l}9 \\
4\end{array}$ & $\begin{array}{l}1 \\
7\end{array}$ & $6,39^{* *}$ & $\begin{array}{c}15,75 \\
(1,42-174,25)\end{array}$ \\
\hline 4 & Koordinasi & $\begin{array}{l}\text { Baik } \\
\text { Kurang } \\
\end{array}$ & $\begin{array}{c}11 \\
2\end{array}$ & $\begin{array}{l}3 \\
5 \\
\end{array}$ & $4,95^{*}$ & $\begin{array}{c}9,17 \\
(1,15-73,24)\end{array}$ \\
\hline
\end{tabular}

Petugas dengan motivasi tinggi memiliki kinerja 23,33 kali lebih baik dibandingkan petugas bermotivasi rendah. Motivasi personal pegawai memengaruhi efektivitas birokrasi pemerintah (Siagian, 2002). Kebutuhan fisik, sosial, maupun aktualisasi diri mampu memotivasi petugas vaksinasi. Sebanyak $66,67 \%$ petugas berpendapat keberhasilan vaksinasi tercapai jika ditunjang dana operasional yang memadai. Anggapan ini memiliki dua pengertian, pertama terjaminnya kebutuhan operasional dan kedua tersedia insentif yang cukup sebagai bentuk penghargaan atas kerja keras petugas. Interaksi sosial petugas dengan masyarakat turut menumbuhkan motivasi ditandai dengan sikap petugas vaksinasi yang menganggap pekerjaannya berkaitan dengan keselamatan manusia $(57,14 \%)$ dan turut berkontribusi dalam kehidupan sosial $(52,38 \%)$. Interaksi ini juga memberikan pengaruh negatif, penolakan masyarakat menurunkan semangat petugas $(42,86 \%)$ sehingga mereka cenderung melayani keluarga/pemilik anjing yang memberikan respon positif $(66,67 \%)$. Aktualisasi diri petugas vaksinasi tercermin dalam tanggung jawabnya terhadap pekerjaan $(66,67 \%)$ dan keinginan untuk meningkatkan kualitas diri melalui pelatihan (71,43\%). Beberapa komponen motivasi terutama yang berimplikasi positif terhadap kinerja dapat dipakai untuk meningkatkan kinerja petugas. 
Semakin tinggi motivasi seseorang semakin tinggi pula kinerja yang dihasilkan (Prawirosentono, 1999).

Pengetahuan juga berasosiasi dengan kinerja ( $\mathrm{P}$ $=0,002$ ), namun kekuatan asosiasinya tidak terukur. Hasil penilaian deskriptif menunjukkan perlunya peningkatan pengetahuan petugas vaksinasi. Pengetahuan dasar tentang rabies sangat terbatas, sebagai contoh $66,67 \%$ petugas beranggapan agen penyebab rabies adalah beberapa jenis mikroorganisme selain virus dan $47,62 \%$ mengatakan dapat ditularkan melalui pakan, air minum, dan udara. Aspek kuantitas lebih dipentingkan daripada kualitas, sebanyak 76,19\% berpendapat tingginya jumlah anjing yang tervaksin merupakan indikator keberhasilan vaksinasi. Hanya $42,86 \%$ yang menolak dengan tegas. pernyataan frekuensi vaksinasi sekali setahun mampu melindungi anjing terhadap rabies dan vaksinasi rutin tidak diperlukan bagi anjing yang sudah tiga kali divaksin. Petugas yang mengidentifikasi faktor penyebab kerusakan vaksin dan cara menyimpan vaksin dengan benar berturut-turut $42,86 \%$ dan $47,62 \%$. Aspek penting seperti frekuensi dan periode vaksinasi sebelumnya harus diikutsertakan dalam pendataan telah dipahami oleh $57,14 \%$ petugas.

Kinerja petugas meningkat 15,75 kali jika sarana penunjang vaksinasi tersedia dalam jumlah memadai. Terabaikannya faktor ini secara langsung dapat menurunkan kinerja petugas, target, bahkan efektivitas vaksinasi itu sendiri. Keluhan tentang minimnya sarana vaksinasi perlu direspon oleh Dinas Pertanian dan Kehutanan kota Ambon. Persentase petugas yang mengakui keterbatasan alat suntik dan termos masing-masing $71,42 \%$ dan $66,67 \%$. Alat pendingin (cold pack) tidak tersedia dan diganti dengan es batu, itu pun tersedia dalam jumlah terbatas seperti pengakuan $61,90 \%$ petugas vaksinasi. Keberhasilan vaksinasi perlu ditunjang dengan laporan yang objektif. Objektifnya laporan vaksinasi tercapai apabila semua aspek pencatatan diperhatikan dengan baik. Petugas yang menilai formulir pendataan vaksinasi dan populasi dibuat terpisah dan selalu tersedia hanya $38,10 \%$ dan $28,57 \%$. Tidak semua petugas membuat buku catatan vaksinasi, $47,62 \%$ bahkan mengaku tidak memilikinya. Sarana lain yang tersedia dalam jumlah memadai adalah stiker tanda vaksinasi, laporan penggunaan vaksin, dan kendaraan operasional, yaitu berturut-turut 47,62\%, 57,14\%, dan $47,62 \%$.

Petugas vaksinasi yang sering berkoordinasi memiliki kinerja 9,17\% lebri' itrggi dibandingkan petugas yang jarang berkoordinasi. Kemampuan berkomunikasi dengan baik merupakan kunci lancarnya koordinasi. Umumnya mereka secara aktif terlibat dalam pertemuan awal $(80,95 \%)$, menyusun rencana dan target vaksinasi $(66,67 \%)$, bekerja sama dalam tim $(80,95 \%)$, serta berkoordinasi dengan instansi lain misalnya petugas Laboratorium Kesehatan Hewan Tipe B $(66,67)$. Sebanyak 57,14\% petugas mengakui supervisi pimpinan jarang bahkan tidak pernah dilaksanakan, hal ini kemungkinan berkaitan dengan kepercayaan pimpinan bahwa petugas vaksinasi dapat menjalankan tanggung jawabnya tanpa perlu diawasi. Jika dihubungkan dengan konteks vaksinasi rabies, koordinasi merupakan proses pengintegrasian dan penyclarasan berbagai kepentingan dan kegiatan dinas yang berwenang, para petugas vaksinasi yang terlibat di dalamnya, serta instansi atau kelompok lain untuk mencapai target vaksinasi yang diharapkan. 
Koordinasi petugas juga dinilai melalui kemudahan para pemilik anjing mengakses informasi tentang pelaksanaan vaksinasi. Sebanyak $73,15 \%$ pemilik anjing mengakui jadwal vaksinasi massal diumumkan oleh pemerintah desa/kelurahan. Data ini menunjukkan tingkat koordinasi antara petugas vaksinasi, Dinas Pertanian dan Kehutanan kota Ambon, dan pemerintah desa/kelurahan telah terjalin baik.

Nilai kinerja petugas vaksinasi dianalisis dengan regresi linear. Model persamaan yang diperoleh berdasarkan hasil transformasi square root, yaitu :

KINERJA_1 $=2,28982+0,06258$ PNGTHUAN + 0,05482 SARANA

Pengetahuan dan sarana bersama-sama memengaruhi kinerja petugas vaksinasi rabies di kota Ambon. Anggapan bahwa vaksin hanya rusak jika terkena sinar matahari dan tidak karena faktor lain turut menjelaskan masih adanya sejumlah petugas yang sering meletakkan vaksin di luar atau membuka tutup termos selama proses vaksinasi dan lalai mengecek kualitas vaksin (52,38\%). Petugas yang sering membawa pulang vaksin kemungkinan dilatarbelakangi oleh pemahamannya bahwa vaksin tetap aman jika disimpan di lemari es rumah tangga asalkan diletakan berdekatan atau di dalam freezer. Keterbatasan informasi menyebabkan masih ada $47,62 \%$ petugas sering mengurangi dosis vaksin secara sepihak. Petugas beranggapan dengan mengurangi dosis vaksin, bahaya yang kemungkinan ditimbulkan jika menvaksin kelompok anjing tertentu (betina bunting, menyusui, dan kondisi lainnya) dapat diminimalkan. Secara teknis, tindakan petugas seperti ini makin mempertinggi resiko kerusakan vaksin dan menurunkan kualitas hasil vaksinasi. Kondisi ini akan terus berlanjut jika petugas tidak segera diberi pemahaman yang benar. Di satu sisi, petugas tidak dapat disalahkan karena pelatihan vaksinasi hanya diberikan sekali sebelum program vaksinasi massal diterapkan. Selain memperbaiki pelaksanaan teknis vaksinasi, peningkatan pengetahuan petugas juga diharapkan meningkatkan kesadaran untuk menyosialisasikan bahaya rabies. Kontribusi mereka sebagai komunikator sangat rendah yaitu $9 \%$, sementara pemilik anjing yang diberi pemahaman oleh petugas vaksinasi lebih termotivasi menvaksin anjingnya $(\mathrm{OR}=9,82 ; \mathrm{P}=0,000)$ dibandingkan jika mendapatkan informasi dari sumber lain. Sosialisasi bahaya rabies melalui komunikasi interpersonal kader kesehatan terbukti efektif meningkatkan pengetahuan dan kewaspadaan pemilik anjing terhadap rabies di Kecamatan Selebar Bengkulu (Yusnelli, 2003).

Ketersediaan sarana vaksinasi memiliki hubungan yang searah dengan kinerja petugas vaksinasi rabies di kota Ambon. Keterbatasan sarana menyebabkan kinerja petugas ikut menurun, demikian pun sebaliknya. Hasil penelitian memperlihatkan keterbatasan sarana penunjang menyebabkan penggunaan alat suntik berulang kali, umumnya $>3$ kali $(85,71 \%)$, dan terlambat mengganti es batu $(76,19 \%)$. Idealnya satu syringe dan jarum suntik untuk sekali pakai, kondisinya menjadi dilematis jika sarana penunjang tersedia dalam jumlah terbatas. Walaupun bukan media penularan rabies, tapi ada beberapa penyakit yang ditularkan melalui darah. Sejumlah 21,33\% pemilik anjing di kota Ambon menilai pemakaian alat suntik bekas dapat menularkan rabies atau penyakit lain pada hewan sehat sehingga mereka menolak berpartisipasi dalam kegiatan vaksinasi. Pada tahun 
2010, Food Agriculture Organization, Departemen Pertanian, bersama Dinas Peternakan propinsi dan se-kabupaten Bali dalam rapat pengendalian rabies menetapkan 1 syringe dan 1 jarum suntik dipakai untuk menvaksin 3 ekor anjing (Anonimous, 2011). Kecenderungan menyesuaikan pekerjaan dengan waktu dan jangkauan masing-masing petugas $(80,95 \%)$ menyebabkan pelayanan vaksinasi terbatas pada anjing yang berhasil ditemui. Seluruh petugas vaksinasi adalah tenaga penyuluh pertanian atau peternakan sehingga mereka akan menyesuaikan waktu dan mendahulukan tugas yang menjadi prioritas. Walaupun anjing dapat dijinakkan, sebanyak $61,90 \%$ petugas memilih untuk menunda vaksinasi jika pemiliknya tidak berada di rumah. Laporan vaksinasi menjadi kurang objektif karena populasi dihitung sebagai jumlah anjing yang ditemui dan cakupan vaksinasi adalah banyaknya anjing yang berhasil divaksin, apalagi formulir pendataan vaksinasi dan populasi yang disediakan tidak spesifik. Penelitian ini menemukan kenyataan bahwa cakupan vaksinasi hanya $36,84 \%$, sangat berbeda Dinas Pertanian dan Kehutanan kota Ambon melaporkan rata-rata cakupan vaksinasi selama 6 tahun terakhir mencapai 78\% (Anonimous, 2010a). Petugas juga kurang berinisiatif membuat buku catatan sehingga berbagai kendala yang ditemui di lapangan jarang dievaluasi secara tertulis.

Ariebowo (2005), Muklis (2006), dan Rahmawati (2007) menyimpulkan pengetahuan dan sarana memengaruhi pelaksanaan imunisasi bayi dan balita. Peneliti lain menemukan adanya hubungan antara ketersediaan sarana vaksinasi rabies dan pemeliharaan anjing dalam upaya pencegahan rabies di Kecamatan Sumbul, Sumatra Utara (Marpaung, 2010). Titik kritis penurunan kualitas vaksin secara signifikan berlangsung saat pelaksanaan di lapangan. Faktor yang menyebabkan turunnya kualitas vaksin adalah kesalahan penanganan dan keterbatasan sarana penunjang vaksinasi sehingga berdampak pada buruknya penanganan rantai dingin (Anonimous, 2009).

Dari hasil dan pembahasan diatas dapat disimpulkan kinerja petugas vaksinasi rabies di kota Ambon secara bivariat berasosiasi dengan motivasi, sarana, dan koordinasi. Peningkatan pengetahuan petugas melalui pelatihan dan jaminan ketersediaan sarana vaksinasi diperlukan untuk meningkatkan kinerja petugas vaksinasi.

\section{DAFTAR PUSTAKA}

Anonim, 2009. Indonesia : Cold Chain Study. Operational Research in Indonesia For More Effective Control of Highly Pathogenic AI. USAID Deliver Project.

. 2010a. Laporan Operasional Vaksinasi Rabies Tahun 2009 di Kota Ambon. Dinas Pertanian dan Kehutanan kota Ambon.

.2010b. Laporan Pengendalian Penyakit Rabies di Kota Ambon. Dinas Kesehatan Kota Ambon.

2011. Indonesia: Cold Chain and Vaccine Management Assessment for the Animal Vaccination Program in Bali Province. USAID Deliver Project.

Ariebowo, H.A. 2005. Analisis Faktor-Faktor Organisasi yang Berhubungan dengan Cakupan Imunisasi Puskesmas di Kabupaten Batang. Tesis, Program Magister Ilmu Kesehatan Masyarakat, Universitas Diponegoro.

Marpaung, O.R. 2010. Hubungan Faktor Internal dan Eksternal Pemilik Anjing dengan Pemeliharaan Anjing dalam Upaya Mencegah Rabies di Kecamatan Sumbul Kabupaten Dairi. 
Tesis, Program Magister Ilmu Kesehatan Masyarakat, Universitas Sumatera Utara.

Mukhlis, 2006. Hubungan Faktor-Faktor Individu dan Organisasi Dengan Kinerja Petugas Vaksinasi di Kabupaten Aceh Timur. Tesis, Fakultas Kedokteran, Universitas Gadjah Mada.

Prawirosentono, S. 1999. Kebijakan Kerja Karyawan. BPFE, Yogyakarta.

Rahmawati, S.P. 2007. Analisis Faktor Sumber Daya Manusia yang Berhubungan dengan Hasil Kegiatan Imunisasi Dasar Bayi oleh Petugas Imunisasi Puskesmas di Kabupaten Blora. Tesis, Ilmu Kesehatan Masyarakat, Universitas Diponegoro.

Riwidikdo, H. 2009. Statistik Penelitian dengan Aplikasi Program R dan SPSS. Pustaka Rihama, Yogyakarta.
Riyanto, A. 2009. Pengolahan dan Analisis Data Kesehatan. Numed, Yogyakarta.

Siagian, E.G.. 2002. Pengaruh Motivasi dan Komitmen Organisasi Terhadap Kinerja Pegawai Sekretariat Daerah Kabupaten Dairi. Tesis, Program Magister Manajemen, Universitas Gadjah Mada.

Wirawan. 2009. Evaluasi Kinerja Sumber Daya Manusia - Teori, Aplikasi, dan Penelitian. Salemba Empat, Jakarta.

Yusnelli. 2003. Efektivitas Komunikasi Interpersonal oleh Kader dalam Meningkatkan Pengetahuan dan Sikap Masyarakat untuk Pencegahan Rabies. Tesis, Fakultas Kedokteran, Universitas Gadjah Mada. 